\title{
PELATIHAN CAREGIVER BAGI DI JAKARTA DENGAN MEDIA AUDIOVISUAL
}

\author{
Titiek Djannatun ${ }^{1}$, Erlina Wijayanti ${ }^{2 *}$, Yusnita $^{2}$ \\ ${ }^{1}$ Bagian Mikrobiologi, Fakultas Kedokteran Universitas YARSI, Jakarta, Indonesia \\ ${ }^{2}$ Bagian Ilmu Kesehatan Masyarakat, Fakultas Kedokteran Universitas YARSI, Jakarta, Indonesia \\ *Penulis Korespondensi: erlina.wijayanti@yarsi.ac.id
}

\begin{abstract}
Abstrak
Edukasi bagi caregiver ODHA tidak selalu diberikan dengan lengkap mengingat kurangnya tenaga kesehatan yang mendampingi dan belum terstandarnya metode pendampingan caregiver. Tujuan kegiatan adalah meningkatkan pengetahuan caregiver pasien HIV/AIDS melalui film edukasi. Sasaran kegiatan adalah pelaku rawat pasien HIV AIDS di Jakarta sebanyak 10 orang. Metode kegiatan yang digunakan berupa pemberian edukasi bagi caregiver mengenai urgensi pengobatan dan motivasi kepatuhan berobat serta testimoni dari role model. Sebanyak 10 orang caregiver terlibat dalam pelatihan. Sebagian besarnya laki-laki (90\%), berusia 35-35 tahun (90\%), dan berpendidikan menengah $(60 \%)$. Dari pelatihan didapatkan rata-rata pengetahuan meningkat dari cukup menjadi baik. Evaluasi terhadap video berdurasi 6 menit yang dibuat adalah diperlukannya animasi yang lebih banyak dan perlu menampilkan pasangan ODHA di sesi testimoni role model. Diharapkan pengabdian masyarakat ini dapat menjadi solusi bagi tenaga kesehatan dalam menyampaikan pendidikan kesehatan untuk pelaku rawat HIV AIDS
\end{abstract}

Kata kunci: media, edukasi, caregiver, ODHA.

\begin{abstract}
Education for HIV caregivers is not always provided in full considering the lack of health workers who assist and have not yet standardized caregiver assistance methods. The purpose of the activity is to improve caregiver knowledge of HIV / AIDS patients through educational films. The target of the activity was 10 people caring for HIV AIDS patients in Jakarta. The method of activity used was in the form of providing education for caregivers regarding the urgency of treatment and motivation for treatment compliance and testimony of role models. A total of 10 caregivers were involved in the training. Most are male (90\%), aged 35-35 years (90\%), and middle class education (60\%). From the training, the average knowledge increased from fair to good. The evaluation of the 6-minute video that was made was the need for more animations and needed to present HIV partners in a testimonial role model session. It is hoped that this community service can be a solution for health workers in delivering health education for HIV/AIDS caregivers
\end{abstract}

Keywords: media, education, caregiver, HIV.

\section{PENDAhuluan}

ODHA adalah sebutan bagi orang dengan HIV/AIDS. HIV adalah virus Human Immunodeficiency yang menyerang sel darah putih. Akibat virus ini, seseorang akan mengalami penurunan sistem kekebalan tubuh. Pengobatan antiretroviral bertujuan menurunkan risiko penularan, memperlambat proses infeksi oportunistik, meningkatkan kualitas hidup penderita HIV, serta menurunkan jumlah virus sampai undetectable (KEMENKES RI, 2014).

Pengobatan antiretroviral akan mulai dilakukan apabila pengidap HIV telah memperoleh konseling, memiliki Pemantau Minum Obat (PMO) dan patuh meminum obat seumur hidup (KEMENKES RI, 2014). Untuk mencapai kepatuhan ODHA dalam berobat, diperlukan pendamping. Pendamping ODHA dapat terdiri dari orang yang juga terinfeksi HIV atau yang disebut dengan Kelompok Dukungan sebaya (KDS). Kelompok Dukungan Sebaya ini dapat terdiri dari dua orang atau lebih dan saling mendukung (Handayani \& Mardhiati, 2018).

Pendamping berperan untuk dapat membantu ODHA dalam menghadapi kondisi psikologis serta stigma dari masyarakat. Lebih jauh, pendamping diharapkan dapat mendorong ODHA untuk dapat berdaya (Nurhayati, 2013). Pasien yang pertama kali terdiagnosis HIV akan di'rujuk' ke KDS untuk mendapat pendampingan. Kelompok dukungan sebaya diwadahi dalam sebuah Yayasan Tingkat Nasional bernama Spiritia. Spiritia ini memiliki perwakilan di tiap provinsi. Di Jakarta, perwakilannya bernama Yayasan Kotex Mandiri. Jumlah pendukung sebaya di wilayah Jakarta berjumlah 
44 orang. KDS selama ini terutama berfungsi memberikan support psikososial dan memotivasi pasien untuk patuh berobat.

Dari hasil wawancara dengan caregiver ODHA, kendala yang dihadapi KDS antara lain banyaknya kasus drop out pengobatan yang disebabkan karena ketakutan pasien terhadap efek samping obat dan banyaknya penggunaan herbal sebagai substitusi antiretroviral. Berdasarkan masalah di atas, diperlukan kegiatan yang dapat meningkatkan pemahaman caregiver ODHA mengenai khasiat obat retroviral, cara mengatasi efek samping obat dan cara memotivasi kepatuhan berobat pasien. Kegiatan ini juga diharapkan dapat menghasilkan media berupa film untuk membantu edukasi pada caregiver ODHA.

\section{BAHAN DAN METODE}

Metode kegiatan yang digunakan berupa pelatihan. Sebelum dan sesudah pelatihan akan diadakan pretes dan postes untuk menilai pengetahuan peserta. Konten yang diberikan berupa metode konseling untuk mendukung pasien HIV-AIDS dibantu dengan media film. Konten film berupa:

a. Mengenal HIV dan AIDS.

b. Urgensi pengobatan antiretroviral.

c. Notifikasi pasangan.

d. Motivasi kepatuhan berobat dengan adanya role model (yang telah berpengalaman meminum obat dan bisa survive selama 15 tahun).

Sasaran kegiatan adalah pelaku rawat pasien HIV AIDS sebanyak 10 orang. Mitra dalam kegiatan ini adalah Yayasan Kotex Mandiri yang memiliki peran sebagai narasumber (role model) dalam pembuatan konten film. Selain juga dapat menjadi penghubung antara caregiver ODHA dengan tim pengabdian masyarakat.

\section{HASIL DAN PEMBAHASAN}

1. Pembuatan Video "Tetap Produktif dengan HIV" Film ini berdurasi 6 menit. Konten film berupa:

a. Mengenal HIV dan AIDS: perbedaan HIV dan AIDS, bahaya window periode, cara penularan dan syarat penularan, antisipasi infeksi oportunistik. (Disampaikan oleh dokter spesialis penyakit dalam)

b. Promosi pengobatan antiretroviral: cara kerja obat, efek samping, pendampingan (sugesti positif dan komunikasi persuasif).

(Disampaikan oleh dokter spesialis penyakit dalam)

c. Notifikasi pasangan, menceritakan mengenai keterbukaan terhadap pasangan dan cara menyampaikan ke keluarga.

(Disampaikan oleh dokter pakar kesehatan reproduksi di masyarakat)

d. Motivasi kepatuhan berobat, disampaikan oleh role model yang memiliki pasangan dan anak HIV negatif. Menceritakan mengenai pengalaman 15 tahun mencapai undetectable condition, efek samping obat yang dialami dan cara mengatasi.

(Disampaikan oleh survivor ODHA)
Kemudian dilakukan pengeditan dan penambahan animasi untuk lebih mempermudah penyampaian pesan kepada penonton.
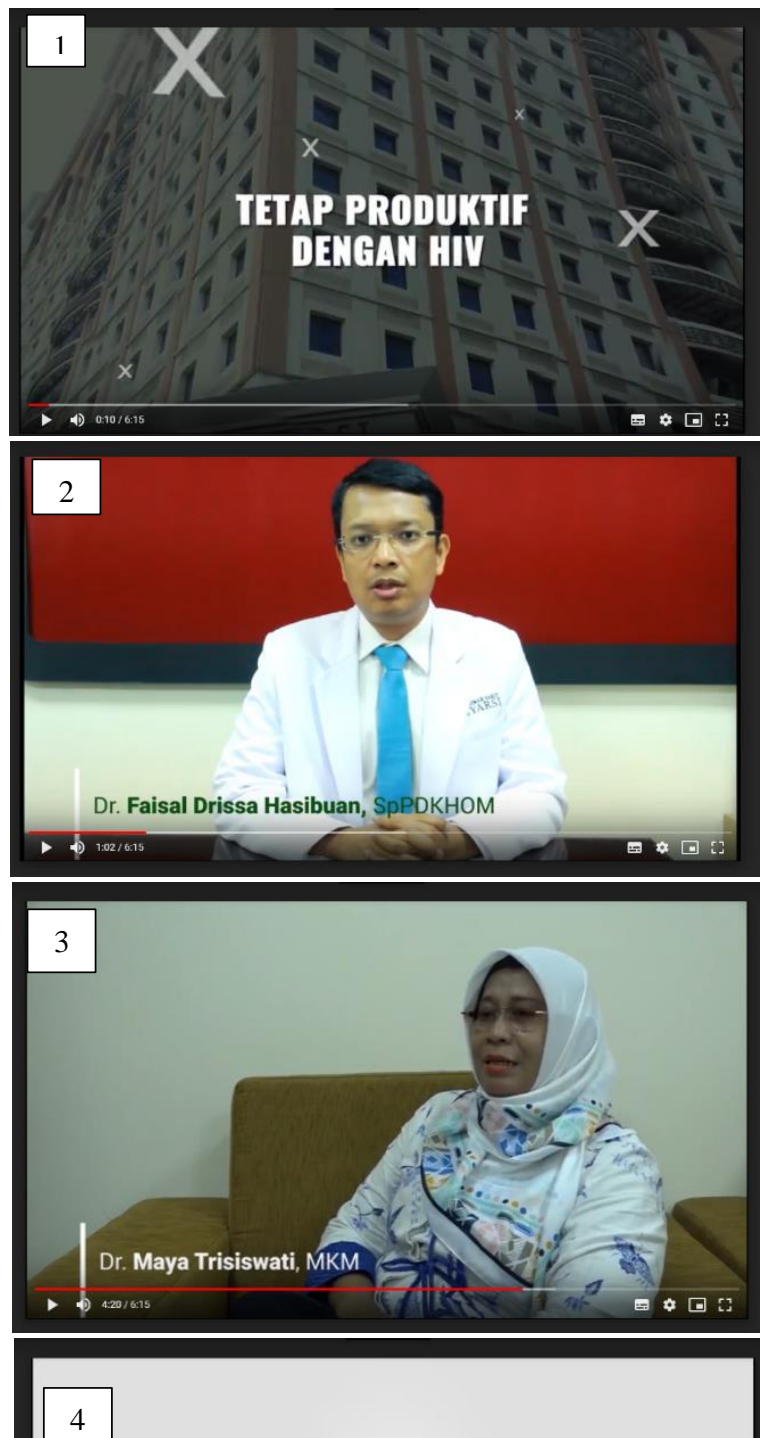

VIRUS HIV/AIDS TERDAPAT DI

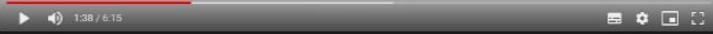




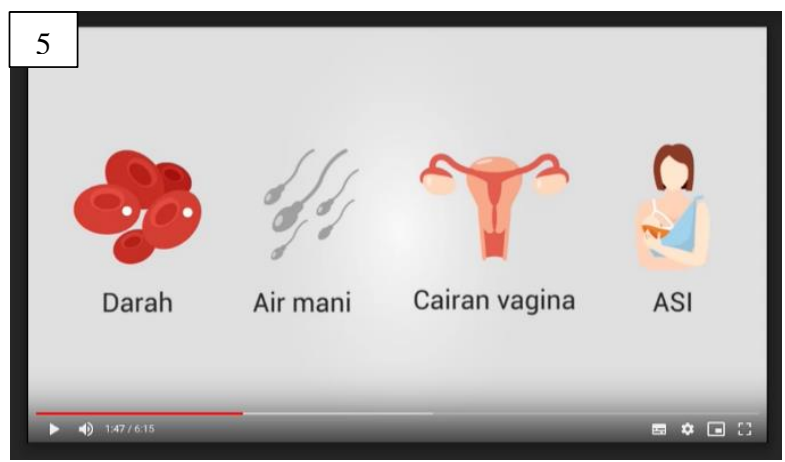

Gambar 1-5. Scene dalam video yang terdiri dari judul video (gambar 1), narasumber/pakar (gambar 2,3), animasi (gambar 4,5)

2. Pelatihan konseling bagi caregiver ODHA Pada Rabu, 26 Juni 2019 dilakukan ujicoba video sekaligus pelatihan konseling bagi caregiver ODHA. Pelatihan dihadiri oleh 10 orang caregiver. Materi pelatihan berupa membangun motivasi untuk mengajak pasien melakukan notifikasi pasangan.

\section{Tabel 1. Karakteristik peserta pelatihan}

\begin{tabular}{lcc}
\hline \multicolumn{1}{c}{ Karakteristik } & n & \% \\
\hline Usia & & \\
20-35 tahun & 1 & $10 \%$ \\
35-45 tahun & 9 & $90 \%$ \\
Jenis kelamin & & \\
Laki-laki & 9 & $90 \%$ \\
Perempuan & 1 & $10 \%$ \\
Tingkat Pendidikan & & \\
Menengah (SMP-SMA) & 6 & $60 \%$ \\
Tinggi (diploma, Sarjana) & 4 & $40 \%$ \\
\hline
\end{tabular}

Dari tabel di atas tampak bahwa sebagian besar caregiver yang menjadi peserta pelatihan adalah lakilaki (90\%), berusia 35-45 tahun (90\%) dan pendidikan menengah $(60 \%)$.

Tabel 2. Hasil pelatihan

\begin{tabular}{cc}
\hline Rata-rata pengetahuan & Nilai \\
\hline Pretest & 76 (cukup) \\
Postest & 80 (baik) \\
\hline
\end{tabular}

$\overline{\text { Tabel di atas memperlihatkan peningkatan pengetahuan }}$ dari cukup menjadi baik.

3. Evaluasi video

Dari ujicoba video didapatkan saran dan masukan sebagai berikut:

a. Penambahan animasi

b. Melibatkan pasangan ODHA dalam testimoni

Dari hasil pelatihan didapatkan kenaikan rata-rata pengetahuan pada peserta. Hal ini dapat disebabkan penggunaaan media yang membantu pemahaman peserta. Sejalan dengan hasil edukasi yang dilakukan oleh Fresia pada tahun 2016 bahwa edukasi melalui metode audiovisual lebih meningkatkan pengetahuan dibandingkan dengan metode tutorial.
Selain peningkatan pengetahuan, diharapkan efek peningkatan motivasi pada pasien ODHA. Menurut teori komunikasi persuasif, faktor pemberi pesan menentukan keberhasilan proses komunikasi. Apabila pemberi pesan adalah orang yang ahli atau memiliki kesamaan status, maka akan meningkatkan penerimaan isi pesan oleh komunikan (Kholid, 2014). Dalam media audiovisual berisi penjelasan dari ahli dan testimoni dari survivor HIV. Keterbatasan kegiatan pengabdian masyarakat antara lain pengukuran pengetahuan dilakukan pada caregiver saja, tapi belum dilakukan pengukuran efek media audiovisual pada peningkatan motivasi caregiver dan pasien.

\section{KESIMPULAN}

Kegiatan pelatihan caregiver ODHA telah dilakukan dengan jumlah peserta sebanyak 10 caregiver. Dengan memakai media audiovisual yang berisi penjelasan mengenai HIV/AIDS, pengobatan dengan ARV, notifikasi pasangan serta pengalaman survivor HIV yang memiliki pasangan dan anak negatif HIV.

Dari hasil pelatihan didapatkan peningkatan pengetahuan peserta dan telah tercipta video sebagai media untuk edukasi caregiver ODHA. Diharapkan melalui kegiatan pelatihan menggunakan video akan lebih meningkatkan motivasi caregiver serta pasien ODHA untuk mengikuti pemeriksaan dan pengobatan secara rutin.

\section{UCAPAN TERIMAKASIH}

Terimakasih diucapkan kepada Universitas YARSI yang telah memberikan dukungan terhadap kegiatan pengabdian masyarakat ini

\section{DAFTAR PUSTAKA}

Fresia, S. (2016). Efektivitas Pemberian Edukasi Berbasis Audiovisual dan Tutorial Tentang Antiretroviral (ARV) Terhadap Kepatuhan Pengobatan pada Pasien HIV/AIDS di Klinik Teratai Rumah Sakit Hasan Sadikin Bandung Tahun 2016. The Indonesian Journal of Infectious Diseases, 3 (2), p.38-45. Retrieved from http://www.ijidrspisuliantisaroso.co.id/index.php/ijid/issue/vie $\mathrm{w} / 7$

Handayani, S., \& Mardhiati R. (2018). Keberlanjutan peran dukungan sebaya di dalam system penanggulangan HIV di tingkat provinsi dan Kota/ Kabupaten Indonesia. Jurnal perilaku dan Promosi Kesehatan. 1 (1), p.44-53. Retrieved from journal.fkm.ui.ac.id/ppk/article/download/2093/ 677

Kemenkes RI. (2014). Peraturan Menteri Kesehatan RI No. 87 tahun 2014 tentang pedoman pengobatan antiretroviral. Kemenkes RI. Jakarta.

Kholid, A. (2014). Promosi Kesehatan. Rajawali Pers: Jakarta

Nurhayati, E. (2013). Stigma dan Diskriminasi Terhadap ODHA di Kota Bandung. Program 
Pascasarjana Program Studi Ilmu Kesehatan Masyarakat Universitas Padjadjaran. Bandung. 